\title{
A Lactococcus lactis gene encodes a membrane protein with putative ATPase activity that is homologous to the essential Escherichia coli ftsH gene product
}

\author{
Dan Nilsson, ${ }^{1}$ Anette A. Lauridsen, ${ }^{1}$ Toshifumi Tomoyasu ${ }^{2}$ and \\ Teru Ogura²
}

Author for correspondence: Dan Nilsson. Tel: +45 45767 676. Fax: +4 4545765455 .

e-mail: dnni@biobase.aau.dk

\footnotetext{
1 Department of Genetics, Chr. Hansen's Laboratorium Danmark AVS, Bøge Allé 10-12, DK2970 Hørsholm, Denmark

2 Department of Molecular Cell Biology, Institute of Molecular Embryology and Genetics, Kumamoto University School of Medicine, Kumamoto 862, Japan
}

\begin{abstract}
A gene, encoding a protein homologous to an essential Escherichia coli protein, FtsH, was identified adjacent to the hpt gene and the trnA operon in the Gram-positive bacterium Lactococcus lactis. The deduced amino acid sequence of the gene product showed full-length similarity to FtsH of E. coli, Yme1p of Saccharomyces cerevisiae and a conserved region found in a new family of putative ATPases. In-frame fusions of $L$. lactis ftsH and phoA1 in $E$. coli, and immunodetection of the $L$. lactis FtsH protein in cell fractions using anti-E. coli FtsH serum showed that $L$. lactis $\mathrm{ftsH}$ was expressed and encodes a membrane protein. When contained on a high copy number plasmid, the $L$.

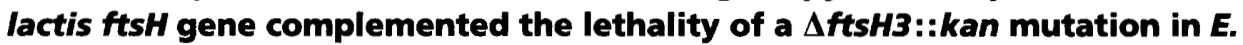
coli at $37^{\circ} \mathrm{C}$ and below, indicating that the $\mathrm{L}$. lactis $\mathrm{ftsH}$ gene can functionally replace the $E$. coli ftsH gene to some extent. The resulting $E$. coli strain showed temperature sensitivity and salt sensitivity. A $L$. lactis mutant with an insertion into $\mathrm{ftsH}$ was salt-, heat- and cold-sensitive. These results suggest that FtsH is somehow involved in stress responses. Southern hybridization analysis indicated that genes homologous to $\mathrm{ftsH}$ of $L$. lactis were also present in Bacillus subtilis, and several Lactobacillus and Leuconostoc species, suggesting high conservation of ftsH in bacterial species.
\end{abstract}

Keywords: Lactococcus lactis, fts $H$, (tma), membrane protein, AAA-protein family

\section{INTRODUCTION}

The facultative anaerobic Gram-positive bacterium Lactococcus lactis subsp. lactis is widely used as an industrial organism for homolactic fermentation. L. lactis has become a model organism for fundamental genetic research on plasmids and plasmid-encoded functions involved in the production of fermented food products. However, the genetic characterization of chromosomally encoded functions in $L$. lactis has only recently been started. We initiated a genetic approach to study purine metabolism in L. lactis and have characterized the hpt gene encoding hypoxanthine guanine phosphoribosyltransferase, an enzyme involved in the salvage of purine bases to the corresponding nucleotides (Nilsson \& Lauridsen, 1992). During this work we detected part of an

The GenBank accession number for the nucleotide sequence reported in this paper is $X 69123$. open reading frame adjacent to $h p t$, transcribed in the same direction, encoding a putative membrane protein.

In this report we describe the cloning and characterization of the L. lactis gene, previously named tma, adjacent to $h p t$ and the tRNA operon $\operatorname{trn} A$ (Nilsson \& Johansen, 1994). We show that the gene is homologous to the Eschericbia coli fts $\mathrm{H}$ gene, and that this gene is conserved in several Gram-positive bacteria, including lactic acid bacteria. We suggest that the gene be designated $f t s H$.

The fts $H$ genes of E. coli and $L$. lactis encode members of a new family of ATPases, the AAA-protein family (Kunau et al., 1993). The family includes both eukaryotic and prokaryotic members which have been reported to be involved in diverse cellular activities, e.g. cell cycle control, protein secretion, peroxisome biogenesis and proteolysis.

E. colifts $H$ mutants show pleiotropic phenotypes: defects in cell growth and cell viability (Ogura et al., 1991; 
Table 1. Bacterial strains and plasmids

\begin{tabular}{|c|c|c|}
\hline Strain or plasmid & Genotype/relevant features & $\begin{array}{l}\text { Source or } \\
\text { reference }\end{array}$ \\
\hline \multicolumn{3}{|l|}{ Escherichia coli } \\
\hline XL1-Blue & $\begin{array}{l}\text { end } A 1 \text { bsd } 17 \text { supE44 thi-1 rec } A 1 \text { gyr } A 96 \text { relA1 } \\
\Delta(l a c)\left[\mathrm{F}^{\prime} \text { pro } A B \text { lac }{ }^{a} Z \Delta \mathrm{M} 15 \operatorname{Tn} 10\right]\end{array}$ & Stratagene, La Jolla \\
\hline $\mathrm{DH} 5 \alpha$ & $\begin{array}{l}\phi 80 \text { lacZ } \Delta \mathrm{M} 15 \Delta(\operatorname{lac} Z Y A-\operatorname{argF}) \mathrm{U} 169 \operatorname{rec} A 1 \\
\text { end } A 1 \text { bsdR } 17 \text { supE44 thi-1 gyr } A 96 \text { rel } A 1\end{array}$ & Hanahan (1983) \\
\hline$S \varnothing 609$ & ara thi rpsL $\Delta$ (pro-gpt-lac) bpt deoD purD & $\begin{array}{l}\text { Jochimsen et al. } \\
\text { (1975) }\end{array}$ \\
\hline $\mathrm{CC} 118$ & $\begin{array}{l}\text { araD139 } \Delta(\text { ara }-l e u) 7697 \Delta \text { lac } \mathrm{X} 74 \text { pho } A \Delta 20 \text { galE } \\
\text { galK thi rpsE rpoB argEam rec } A 1\end{array}$ & $\begin{array}{l}\text { Manoil \& Beckwith } \\
\text { (1986) }\end{array}$ \\
\hline AR423 & $\begin{array}{l}\text { met gal supE bsdR sfiC } \Delta(\operatorname{srl}-\operatorname{rec} A) 306: \operatorname{Tn}^{\top} \mathrm{Tn} 10 \\
\Delta f t s H 3:: k a n\left[\mathrm{pAR} 171 \mathrm{ftsH} r e p^{\mathrm{ts}} \mathrm{Cm}^{\mathrm{R}}\right]\end{array}$ & $\begin{array}{l}\text { A kiyama } \text { et al. } \\
\text { (1994a) }\end{array}$ \\
\hline AR3120 & $\begin{array}{l}\text { met gal supE bsdR sfiC } \Delta(\operatorname{srl}-\operatorname{rec} A) 306:: \operatorname{Tn} 10 \\
\Delta f t s H 3:: \text { kan }[\mathrm{pLN} 32 \text { L. lactis fts } H]\end{array}$ & This study \\
\hline \multicolumn{3}{|l|}{ Lactococcus lactis } \\
\hline CHCC285 & Wild-type & $\begin{array}{l}\text { Nilsson \& Lauridsen } \\
\text { (1992) }\end{array}$ \\
\hline MG1363 & Plasmid-free & Gasson (1983) \\
\hline DN4302 & MG1363 ftsH::pLN43 & This study \\
\hline \multicolumn{3}{|l|}{ Plasmids } \\
\hline pBluescript $\mathrm{KS}+$ & Cloning vector $\left(A p^{R}\right)$ & Stratagene \\
\hline pBluescript SK- & Cloning vector $\left(\mathrm{Ap}^{\mathbf{R}}\right)$ & Stratagene \\
\hline pVS2 & Ery $^{\mathrm{R}} \mathrm{Cm}^{\mathrm{R}}$ & von Wright (1987) \\
\hline $\mathrm{pV} 2$ & $\begin{array}{l}\text { pBluescript } \mathrm{KS}+\text { with a } 1.3 \mathrm{~kb} \mathrm{ClaI}-\mathrm{HpaII} \\
\text { fragment }\left(\mathrm{Ery}^{\mathrm{R}}\right) \text { from } \mathrm{pVS} 2\end{array}$ & $\begin{array}{l}\text { Svend E. W. Hansen } \\
\text { (personal } \\
\text { communication) }\end{array}$ \\
\hline pAR171 & $f t s H r e p^{\text {ts }} \mathrm{Cm}^{\mathbf{R}}$ & $\begin{array}{l}\text { Akiyama et al. } \\
\text { (1994a) }\end{array}$ \\
\hline pLN2 & $\begin{array}{l}\text { pBluescript SK - with a } 1.9 \mathrm{~kb} E c o \mathrm{RI}-M b o \mathrm{I} \\
\text { fragment }\left(f t s H^{\prime}\right) \text { from } \mathrm{CHCC} 285\end{array}$ & $\begin{array}{l}\text { Nilsson \& Lauridsen } \\
\text { (1992) }\end{array}$ \\
\hline pLN3 & $\begin{array}{l}\text { pBluescript SK - with a } 1.3 \mathrm{~kb} \text { HindIII-MboI } \\
\text { fragment }\left({ }^{\prime} f t s H^{\prime}\right) \text { from } \mathrm{CHCC} 285\end{array}$ & $\begin{array}{l}\text { Nilsson \& Lauridsen } \\
(1992)\end{array}$ \\
\hline pLN22-27 & pLN2 ftsH::Tn5pho $A 1$ & This study \\
\hline pLN30 & $\begin{array}{l}\text { pBluescript KS + with a } 7 \cdot 3 \mathrm{~kb} S p e \mathrm{I} \text { fragment } \\
(\text { bpt fts } H) \text { from } \mathrm{CHCC} 285\end{array}$ & This study \\
\hline pLN32 & $\begin{array}{l}\text { pBluescript KS + with a } 3.2 \mathrm{~kb} \mathrm{EcoRI} \mathrm{fragment} \\
(f t s H) \text { from } \mathrm{pLN} 30\end{array}$ & This study \\
\hline pLN39 & $\begin{array}{l}\text { pBluescript } \mathrm{KS}+\text { with a } 1.0 \mathrm{~kb} \text { HindIII-EsoRI } \\
\text { fragment (' } f t s H) \text { from pLN32 }\end{array}$ & This study \\
\hline $\mathrm{pLN} 43$ & $\begin{array}{l}\text { pV2 with a } 1.3 \mathrm{~kb} \text { EcoRV fragment }\left({ }^{\prime} f t s H^{\prime}\right) \text { from } \\
\text { pLN32 }\end{array}$ & This study \\
\hline
\end{tabular}

Tomoyasu et al., 1993a), defects in protein assembly into and through the membrane (Akiyama et al., 1994a, b; Tomoyasu et al., 1993a) and a defect in a proteolytic pathway (Herman et al., 1993). A Bacillus subtilis ftsH mutant shows salt sensitivity (Geisler \& Schumann, 1993). However, it has not satisfactorily been demonstrated how fts $H$ mutations cause these diverse defects, and what the function of $\mathrm{FtsH}$ is. In this respect, it is interesting to know the structural similarity and functional relationship of FtsH in Gram-negative and Gram-positive bacteria. Comparative studies on the FtsH proteins in Gram-positive and Gram-negative bacteria will provide better understanding of the function of this highly conserved putative membrane ATPase.

\section{METHODS}

Bacterial strains, plasmids and media. The bacterial strains and plasmids used are listed in Table 1. L. lactis was grown in M17 medium (Oxoid), containing $0.5 \%$ glucose, routinely at $30^{\circ} \mathrm{C}$. E. coli and B. subtilis were grown in L-broth (Miller, 1972) at $37^{\circ} \mathrm{C}$ unless otherwise stated. The phosphate-buffered minimal medium of Clark \& Maaløe (1967) was used for selection of $\mathrm{S} \varnothing 609 \mathrm{Hpt}^{+}$as described previously (Nilsson \& Lauridsen, 1992). For growth of plasmid-containing cells, the 
media contained appropriate antibiotics: E. coli, ampicillin (50 $\mathrm{mg} \mathrm{l}^{-1}$ ), kanamycin (300 or $30 \mathrm{mg} \mathrm{l}^{-1}$ ), chloramphenicol $\left(10 \mathrm{mg} \mathrm{l}^{-1}\right)$; L. lactis, erythromycin $\left(1 \mathrm{mg} \mathrm{l}^{-1}\right)$. For identification of blue PhoA ${ }^{+}$colonies on agar plates, $40 \mathrm{mg} \mathrm{XP}^{-1}$ (5-bromo4-chloro-3-indolyl phosphate, Sigma) was added.

DNA manipulations and sequencing. $L$. lactis chromosomal DNA was isolated according to Johansen \& Kibenich (1992). $E$. coli and $B$. subtilis chromosomal DNA was isolated as described by Silhavy et al. (1984) and E. coli plasmids as described by Birnboim \& Doly (1979). The use of restriction enzymes, T4 DNA ligase and calf intestine alkaline phosphatase were as recommended by the suppliers (Boehringer Mannheim, Promega, Stratagene). Plasmid transformation of E. coli and $L$. lactis was performed according to Mandel \& Higa (1970) and Holo \& Nes (1989), respectively. The nucleotide sequence of both strands of DNA was determined by the dideoxy method (Sanger et al., 1977). Universal primers from Stratagene or customized primers were used as sequencing primers. All nucleotide sequence data were processed and the deduced amino acid sequences compared using the GCG software package, version 7.0 (Devereux et al., 1984) and EMBL nucleotide sequence database release 37.0 .

Cloning of $\mathbf{f t s} \boldsymbol{H}$. A L lactis strain CHCC285 chromosomal DNA library, containing $1-10 \mathrm{~kb}$ SpeI restriction fragments in the bacteriophage vector $\lambda$ Zap II (Stratagene) was used. By selecting for $\mathrm{Hpt}^{+}$colonies of E. coli strain S0609 (Nilsson \& Lauridsen, 1992), we isolated clone $\lambda \mathrm{LN} 2$ containing a $7.3 \mathrm{~kb}$ and a $1.3 \mathrm{~kb}$ SpeI fragment. The $7.3 \mathrm{~kb}$ fragment, containing the $b p t$ and $f t s H$ genes, was subcloned in the plasmid vector pBluescript KS + (Stratagene) resulting in pLN30 (Table 1).

Construction of pLN2::Tn5phoA1. Plasmid pLN2 (Table 1), which contains the first 441 codons of the $f t s H$ gene, was used to transform E. coli strain CC118. Following infection of CC118(pLN2) with irex:: Tn5phoA1 b221 cI857 Pam3 (Gutierrez et al., 1987), blue colonies on LB XP agar plates $\left(\mathrm{PhoA}^{+}\right.$) that were $\mathrm{Kan}^{\mathrm{R}}$ and $\mathrm{Ap}^{\mathrm{R}}$, were selected and pooled. Plasmids were isolated and used to transform CC118 to PhoA ${ }^{+}$, $A p^{\mathrm{R}}$ and $\mathrm{Kan}^{\mathrm{R}}$. Six independent $\mathrm{pLN} 2:: \operatorname{Tn} 5 p b o A 1$ isolates were obtained.

Identification of $L$. lactis FtsH in E. coli. Various E. coli extracts from strains containing plasmids were used for SDS-PAGE and subsequently blotted semi-dry to nitrocellulose as described by Ipsen \& Larsen (1988). The nitrocellulose was subsequently immunostained (Larsen et al., 1992) using the anti-E. coli FtsH serum described previously (Tomoyasu et al., 1993b).

Cell-fractionation of $L$. lactis. Cells were grown in $400 \mathrm{ml}$ of M17 medium to an $\mathrm{OD}_{600}$ of $0 \cdot 9-1 \cdot 0$, harvested and resuspended in $5 \mathrm{ml} 30 \mathrm{mM}$ sodium phosphate ( $\mathrm{pH} \mathrm{6.8)} \mathrm{containing} 0.4 \mathrm{M}$ sucrose and $1 \mathrm{mg}$ lysozyme $\mathrm{ml}^{-1}$. After incubation at $37^{\circ} \mathrm{C}$ for $1 \mathrm{~h}$, the cells were harvested, washed twice with $30 \mathrm{mM}$ sodium phosphate containing $0.4 \mathrm{M}$ sucrose, resuspended in $5 \mathrm{ml}$ $10 \mathrm{mM}$ sodium phosphate ( $\mathrm{pH} 6.8$ ) and sonicated. After ultracentrifugation of the cell extract $\left(100000 \mathrm{~g}, 1 \mathrm{~h}\right.$ at $\left.4{ }^{\circ} \mathrm{C}\right)$, the supernatant (cytoplasmic) fraction was collected. The pellet (membrane) fraction was resuspended in $10 \mathrm{mM}$ sodium phosphate containing $1 \mathrm{M} \mathrm{NaCl}$ and ultracentrifuged as above. The supernatant and pellet were collected separately. The supernatant was desalted by gel filtration (Sephadex G-25M, Pharmacia).

The collected fractions were used for SDS-PAGE, blotted to nitrocellulose and immunostained with anti-E. coli $\mathrm{FtsH}$ serum as described above.

Southern hybridization analysis. A $1.0 \mathrm{~kb} H i n \mathrm{dIII}-K p n \mathrm{I}$ (the $K p n I$ site originates from the polylinker of pBluescript SK-) restriction enzyme fragment of plasmid pLN3 (Table 1) contains an internal part of the $L$. lactis $f t s H$ coding region. This fragment was used as probe in Southern hybridization analysis with ScaI-digested chromosomal DNA from various bacterial strains, using the ECL Gene Detection System, version 2 (Amersham) as follows. In the hybridization buffer $\mathrm{NaCl}$ was added to a final concentration of $1.0 \mathrm{M}$; primary washes were in $2 \times \mathrm{SSC}, 1 \mathrm{M}$ urea, at $25^{\circ} \mathrm{C}$. All other procedures including probe labelling, DNA transfer and signal detection were as described by Amersham. The molecular mass markers were obtained from Gibco BRL.

To verify the integration of pLN43 (Table 1 ) into the $f t s H$ gene of L. lactis strain DN4302 ftsH::pLN43, a $1.3 \mathrm{~kb}$ EcoRV internal fragment of $f t s H$ was used as probe in Southern hybridization analysis with EcoRI-digested chromosomal DNA from DN4302 and L. lactis strain MG1363 wild-type. Standard conditions as recommended by Amersham were used.

\section{RESULTS}

\section{Nucleotide sequence of $L$. lactis $\mathrm{fts} H$}

Adjacent to the $b p t$ gene and $\operatorname{trn} A$ operon of $L$. lactis, a gene $\left(f t s H^{\prime}\right)$ was found (Nilsson \& Lauridsen, 1992; Nilsson \& Johansen, 1994). The complete $f t s H$ gene was cloned and the nucleotide sequence was determined. The sequence of the last 24 codons of $b p t$ and the entire $f t s H$ gene is shown in Fig. 1. A possible ribosome binding site (Ludwig et al., 1985; Shine \& Dalgarno, 1974) and a putative promoter (Koivula et al., 1991) are located upstream of $f t s H$ (Fig. 1). The putative promoter contains the sequence 5' ATATG $3^{\prime}$ in the -16 region (consensus 5'RTRTG 3' where $\mathrm{R}=$ purine), which is found in strong B. subtilis promoters (Henkin et al., 1988; Moran et al., 1982). A potential stem-loop structure followed by five Ts (nucleotides 82-101) was located between the hpt and $f t s H$ coding regions. The translation stop codon of the $f t s H$ gene was located in the loop of a potential transcription terminator structure (nucleotides 23522391).

Analysis of the deduced amino acid sequence of the $f t s H$ gene revealed a purine nucleotide binding site motif (residues 233-240 and 288-293) (Walker et al., 1982). Two putative transmembrane sequences can be predicted (residues 1-29 and 136-158) (Kyte \& Doolittle, 1982). The transmembrane sequence (residues 136-158) and the region containing the purine nucleotide binding site are separated by a very glycine rich sequence (residues 159-170, GGMGARGGGGGG).

\section{Comparison of $L$. lactis FtsH with other proteins}

Database searches for genes encoding similar amino acid sequences revealed that the deduced amino acid sequence of L. lactis fts $H$ was $47 \%$ identical to that of E. coli fts $H$ (Tomoyasu et al., 1993a) and 36\% identical to that of Saccharomyces cerevisiae Yme1 (Thorsness et al., 1993). The deduced $L$. lactis FtsH amino acid sequence contains a region of 200 amino acid residues that reveals similarity to conserved domains in the AAA-protein family of putative ATPases (Erdmann et al., 1991; Kunau et al., 1993). In this region the $L$. lactis FtsH amino acid 
TIGGACTACGAAGAAAACTATCGTAATCITCCATATGTCGGAGTTITAAAACCAGAAGTTTATAACAAATAATTCGTTGATITIAGTCATCTAAAGTITT

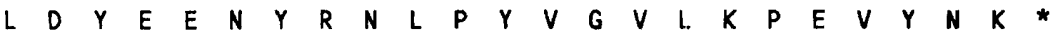

$$
-35-16 \quad-10
$$

TCTCAGACTAAAGTATGAAAAAATCTCTGACCAATACTTACTATIAGCATTCCAAAAGGAATATGCTATMACTAGgTATAGCTGTTATTGACTAGCCTG 200

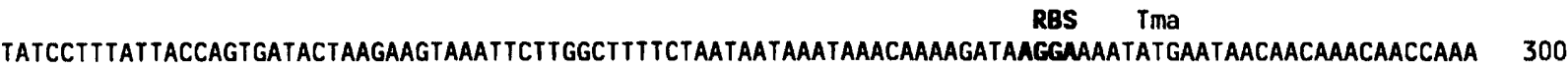

1

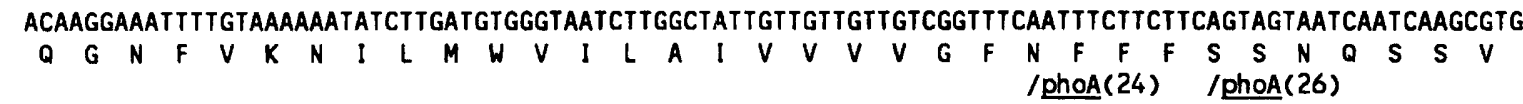
GATAAAAT TAGCTATTCACAAT TGATGACGAAACTTGACGGTAACAAGATTGAAAACGTCACAATGCAACCTICTGATAGCTTAATTACTGTAACAGGTG

\section{/phOA(25)/phOA(27)}

AATATAAAGAACCTGTAAAAGTAAAAGGAACAAATAATTTCCCACTITIAGGCAATICTAGTAGTGAAGTTAAAAACT TCCAAGCTTATATTATTCCAAC $\begin{array}{llllllllllllllllllllllllllllllllll}Y & K & E & P & V & K & V & K & G & T & N & N & F & P & L & L & G & N & S & S & S & E & V & K & N & F & 0 & A & Y & I & I & P & T\end{array}$ ECORV /phOA(22)/PhOA(23)

TGACAGTGTTGTCAAGGATATCCAAAATGCAGCTAAAAGTAATGATGTAAAACTTAGTGTTGTTCAAGCTTCATCAAGTGGTATGTGGGTTCAAATTCTC

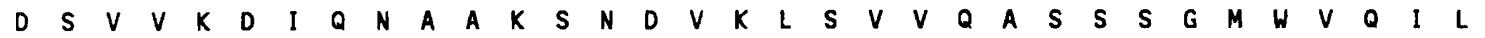

TCATACATCATTCCAATGCTTCTATTTGTTGGTATCTTCTGGCTCATGATGGGCGGAATGGGCGCTCGTGGCGGAGGCGGCGGTGGAAATCCGATGTCCT $\begin{array}{llllllllllllllllllllllllllllllllll}S & Y & I & I & P & M & L & L & F & V & G & I & F & W & L & M & M & G & G & M & G & A & R & G & G & G & G & G & G & N & P & M & S & F\end{array}$ TCGGTAAATCTCGTGCTAAACAACAAGATGGTAAAACATCTAAAGTTCGTTTTGCTGACGTTGCCGGTICTGAAGAGGAAAAACAAGAGCTTGTAGAAGT $G \begin{array}{llllllllllllllllllllllllllllllll} & K & R & A & K & Q & Q & D & G & K & T & S & K & V & R & F & A & D & V & A & G & S & E & E & E & K & Q & E & L & V & E & V\end{array}$

YGTTGATTTCCTTAAAAATCCGAAAAAATATCATGATTTAGGAGCTCGTATCCCAGCAGGTGTTCTTCTTGAAGgCCCTCCAGGTACAGGTAAAACATTG $\begin{array}{llllllllllllllllllllllllllllllllll}V & D & F & L & K & N & P & K & K & Y & H & D & L & G & A & R & I & P & A & G & V & L & L & E & G & P & P & G & T & G & K & T & L\end{array}$

CTTGCTAAGGCTGTTGCCGGTGAAGCAGGAGTTCCTTTCTATAGTATCTCAGGTTCTGATTTCGTTGAAATGTTTGTCGGTGTTGGTGCCTCACGTGTCC

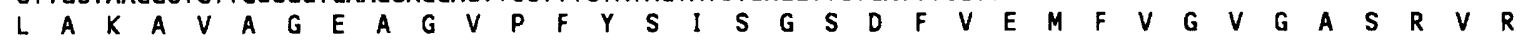
GTGACTTATTTGAAAATGCTAAGAAAACTGCACCATCAATTATCTTTATTGATGAAATTGATGCTGTTGGTCGTCAACGTGGTGCAGGTCT TGGTGGTGG $\begin{array}{llllllllllllllllllllllllllllllllll}D & L & F & E & N & A & K & K & T & A & P & S & I & I & F & I & D & E & I & D & A & V & G & R & Q & R & G & A & G & L & G & G & G\end{array}$

TAACGATGAACGTGAACAAACCCTTAACCAAT TGCTCGTTGAAATGGATGGTTTCCAAGATGATGGCAACTCAGTAATCGTTATTGCTGCAACTAACCGT N $D$ D $E \begin{array}{lllllllllllllllllllllllllllllll} & R & E & Q & T & L & N & Q & L & L & V & E & M & D & G & F & Q & D & D & G & N & S & V & I & V & I & A & A & T & N & R\end{array}$

TCAGATGTGCTTGACCCAGCGCTTITACGTCCAGGTCGTTTTGACCGTAAAGTCTTGGTCGGAGCTCCAGATGTTAAAGGTCGTGAAGCCGTTCTTAAAG

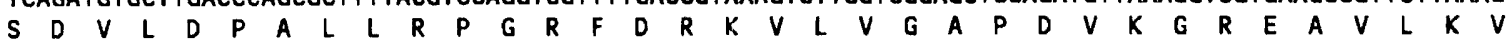
TICATGCTAAAAACAAACCTTTAGCAAGTGATGTTGATTTGCACAATGT TGCTACACAAACTCCAGGCTATGTCGGAGCTGATTTGGAAAATGTTTTGAA $\begin{array}{lllllllllllllllllllllllllllllllll}H & A & K & N & K & P & L & A & S & D & V & D & L & H & N & V & A & T & Q & T & P & G & Y & V & G & A & D & L & E & N & V & L & N\end{array}$ TGAAGCTGCACTTGTTGCTGCACGTCAAAATAAAAAAGAAATCAATGCTGCTGACATTGATGAAGGAATGGACCGTGCAATGGCTGGTCCAGCTAAGAAA

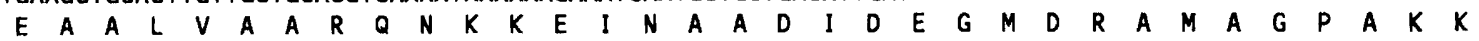

GATCGTATTCAAICAATGCGCGAACGTGAGATCGTGGCTTACCACGAAGCAGGTCACGCTATTGTTGGACTCGTTCTTGAAAATGATCTACTGTTCGTA $\begin{array}{lllllllllllllllllllllllllllllllllll}D & R & I & Q & S & M & R & E & R & E & I & V & A & Y & H & E & A & G & H & A & I & V & G & L & V & L & E & N & G & S & T & V & R & K\end{array}$

AAGTTACCGTTGTTCCACGTGGACGCATCGGTGGTTACATGCTTGCTCTICCAGATGAAGAAATCATGCAACCAACTAATTTCCATCTTCAAGACCAACT

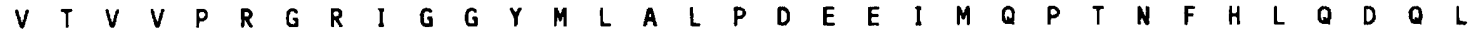
ECORV

TGCCAGCCTTATGGGTGGACGACTIGGTGAAGAAATTGTCTTTGGTGTAGCTACTCCAGGGGCATCAAATGATATCGAAAAAGCAACACACATTGCTCGT

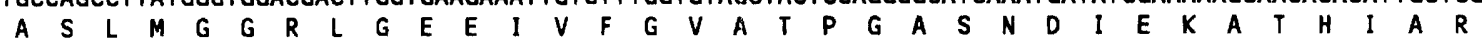

TCAATGGTAACTGAATATGGGATGTCTAAGAAACTTGGTATGGTATCTTATGAAGGAGACCATCAAGTATTTATTGGTCGCGACTATGGTCAAACTAAGA $\begin{array}{lllllllllllllllllllllllllllllllllll}S & M & V & T & E & Y & G & M & S & K & K & L & G & M & V & S & Y & E & G & D & H & O & V & F & I & G & R & D & Y & G & Q & T & K & T\end{array}$ CTIACTCAGAAGCAACTGCTGTTATGATTGATGATGAAGTGCGTCGTATTCTCGGTGAAGCTTATGACCGTGCTAAAGAAGCAATTGAAACACACCGTGA $\begin{array}{llllllllllllllllllllllllllllllllll}Y & S & E & A & T & A & V & M & I & D & D & E & V & R & R & I & L & G & E & A & Y & D & R & A & K & E & A & I & E & T & H & R & E\end{array}$ GCAACATAAAGCAATTGCGGAAGCTCTGCTTAAATATGAAACACTTGATGCGAACAAATCATGTCACTCTTCAAAACAGGAAAAATGCCTGATGAAGCA Q

GCGGCAGCAGAAGTACCAGAACCAAAAACATTTGAAGAATCTCTCAAAGATGCAAATGCGAATGTTGATGATTTTTCAAACATTAATATCTATAATGGTG $\begin{array}{llllllllllllllllllllllllllllllllllll}A & A & A & E & V & P & E & P & K & T & F & E & E & S & L & K & D & A & N & A & N & V & D & D & F & S & N & I & N & I & Y & N & G & D\end{array}$ ATGAAAAAACAGATTCTAAACCAGAAGAAAATAAGgAAAAATCAGAAGATGAAACAGCCGAATAAGGCTGTTTTTCTTTTTTTTATGTTTTAGAATAAGT

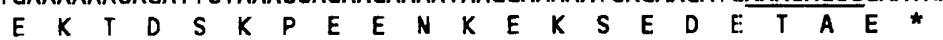

Fig. 1. For legend see facing page. 
sequence is $71 \%$ identical to that of E. coli $\mathrm{FtsH}$ and 31 amino acid residues are identical among all sequences shown in Fig. 2.

\section{Localization of L. lactis FtsH in the membrane}

A system using $\operatorname{Tn} 5$ pho $A 1$ to generate protein fusions between the product of a target gene and alkaline phosphatase (AP) has been developed to detect genes encoding membrane and periplasmic proteins in E. coli (Manoil \& Beckwith, 1985, 1986). Fusion of AP to a periplasmic protein or to a periplasmic domain of a membrane protein is essential for AP activity. Selection for $\mathrm{Tn} 5 p h o A 1$ insertions in pLN2 (Table 1, contains the first 441 codons of $L$. lactis fts $H$ ) resulted in six different plasmids (pLN22-pLN27, Table 1) expressing AP activity in $E$. coli. The fusion points between Tn $5 p h o A 1$ and pLN2 in pLN22-27 were determined by DNA sequencing. All the insertions were located in the $f t s H$ coding region between nucleotide 467 and 663 (codons 64-129) (Fig. 1).

To further analyse the localization of the $L$. lactis FtsH protein in the cell, we carried out Western blotting analysis of fractionated $L$. lactis cell extracts with anti-E. coli FtsH serum, which also reacts with FtsH of L. lactis. Sonicated cell extracts from L. lactis strain MG1363 and DN4302 ftsH::pLN43 (described below) were fractionated into cytoplasmic and membrane fractions by ultracentrifugation. The membrane fraction was washed with $1 \mathrm{M} \mathrm{NaCl}$ and separated into supernatant and pellet. In Fig. 3(a) and (b) (lanes 1-3) a SDS-polyacrylamide gel of the various fractions of cell extract of MG1363 and DN4302 blotted to nitrocellulose and gold-stained is shown. No significant differences in the protein patterns of the cytoplasmic or membrane fractions of MG1363 and DN4302 were found (Fig. 3a and b, lanes 1 and 3), whereas, the supernatants of the salt-washed membranes differed in protein patterns (Fig. 3a and b, lanes 2). The anti-E. coli $\mathrm{FtsH}$ serum only detected FtsH from MG1363 and a truncated form of FtsH from DN4302 in the pellets of the salt-washed membrane fractions (Fig. $3 a$ and $b$, lanes 6).

It is concluded from the results described above, that FtsH of L. lactis is an integral membrane protein spanning the membrane twice with the region flanked by these hydrophobic stretches protruding outside the cell, and that it has a large cytoplasmic carboxy-terminal part with a putative ATP-binding domain (Fig. 4). Such overall features of the L. lactis FtsH topology are consistent with those of the E. coli homologue, FtsH (Tomoyasu et al., 1993b), except that L. lactis FtsH has a larger outside domain than E. coli FtsH.

\section{Complementation of $\Delta f t s H 3:$ :kan in $E$. coli with $\mathrm{ftsH}$ of $L$. lactis}

Since the deduced amino acid sequences of $f t s H$ from $L$. lactis and E. coli showed a high degree of identity, we were interested to know whether or not the L. lactis fts $H$ gene could complement a fts $H$ mutation in E. coli.

The E. coli strain AR423 $\Delta f t s H 3:$ : kan (pAR171 ftsH repts $\mathrm{Cm}^{\mathbf{R}}$ ) shows temperature-sensitive growth, because the replication of the plasmid pAR171, containing the essential fts $\mathrm{H}$ gene and a chloramphenicol $(\mathrm{Cm})$ resistance marker, is defective at $42{ }^{\circ} \mathrm{C}$ (Akiyama et al., 1994a).

The plasmid $\mathrm{pLN} 32$ contains the entire $L$. lactis fts $H$ gene, whereas the plasmids pLN2 and pLN39 contain various parts of the $L$. lactis fts $H$ gene, all cloned in the vector pBluescript $\mathrm{KS}+$ or pBluescript $\mathrm{SK}$ - containing ampicillin resistance $\left(A p^{R}\right)$ markers (Fig. 5a, Table 1). These plasmids were used to transform strain AR 423 by selection for $\mathrm{Ap}^{\mathrm{R}}$ at $30^{\circ} \mathrm{C}$. The strains obtained were incubated in $\mathrm{LB}$ at $42^{\circ} \mathrm{C}$ for $6 \mathrm{~h}$, and then plated on $\mathrm{LB}$ agat at $30^{\circ} \mathrm{C}$. The plasmid content of the colonies was tested by streaking on $\mathrm{LB}$ agar containing $\mathrm{Ap}$ or $\mathrm{Cm}$; and the possession of the $\Delta f t s H 3:$ :kan mutation was tested by streaking on LB agar containing Kan. From transformants containing the entire $L$. lactis $f t s H$ gene on pLN32, $\mathrm{Cm}^{\mathrm{s}}$ colonies could be isolated with a frequency of approximately $40-50 \%$, indicating that these had lost pAR171, containing the E. coli fts $H$ wild-type. Such colonies were all $A p^{R}$ and $\mathrm{Kan}^{\mathrm{R}}$, indicating that these had retained pLN32, containing the $L$. lactis fts $H$ gene, and the mutation $\Delta f t s H 3:$ : kan. Colonies of transformants with $\mathrm{pLN} 2$ and $\mathrm{pLN} 39$, containing only part of L. lactis fts $H$, were all $\mathrm{Ap}^{\mathrm{R}}, \mathrm{Cm}^{\mathrm{R}}$ and $\mathrm{Kan}^{\mathrm{R}}$, showing that no loss of pAR171 was obtained. Thus PAR171, and hereby the E. coli wild-type $f t s H$ gene, can be lost only from strains containing the complete $L$. lactis fts $H$ gene. One strain, AR3120 $\Delta f t s H 3:$ : kan (pLN32 L. lactis ftsH), was saved for further studies.

Western blots with anti-E. coli FtsH serum were performed using extracts of AR423, AR423 containing the plasmids in Fig. 5(a) and AR3120 to detect the gene products of $E$. colifts $H$ and/or $L$. lactis fts $H$ (Fig. 5b). The $E$. coli FtsH protein could be detected in the AR423 derivatives but not in AR3120, whereas the L. lactis FtsH protein was detected in AR423(pLN32) and AR3120. No L. lactis fts $H$ product was detected in AR423, AR423(pLN39), AR423(pLN2) or AR423(pKS +). This

\footnotetext{
Fig. 1. Nucleotide sequence of the $\mathrm{L}$. lactis $\mathrm{ftsH}$ gene. The numbers to the right indicate nucleotide positions ('hpt, nucleotides 1-72; ftsH, nucleotides 278-2365, 696 codons). The deduced amino acid sequences of ' $h p t$ and $\mathrm{ftsH}$ (FtsH) are shown in one-letter code below, with the translation stop codons indicated by asterisks. The numbers to the left indicate the deduced amino acid residue position of FtsH. The putative ribosome binding sites (RBS) and promoter regions ( -35 , $-16,-10)$ are indicated. Two putative stem-loop structures are underlined. The Tn5phoA1 insertions in pLN22-27 are indicated above the sequence. The EcoRV sites used to construct the integration plasmid pLN43 are shown above the sequence.
} 
LIFtsH MNNNKQPKQGNFVKNILMWVILAIVVVVGFNFFFSSNQSSVDKISYSQLMTKLDGNKIENVTMQPSDSLITVTGEYKEPVKVKGTNNFPLLGNSSSEVKN 100 ECF tsH $\ldots . \ldots \ldots .$. MAKNLILWLVIAVVLMSVFOS.FGPSESNGRKVDYSTFLQEVNNDQVREARINGREINVT ....................KKDSNR 65 Yme 1p KQANVAVSHAMLATREQEANKDLTSPDAQAAFYKLLLQSNYPQYVVSRFETPGIASSPECMELYMEALQRIGRHSEADAVRQNLLTASSAGAVNPSLASS 192

LIFTSH FQAYIIPTDSWVDI INAAKSNDVKLSVVQASSSGMWVQILSYI IPMLLFVGI FWLMMGGMGARGGGGGGNPMSFGKSRAKQQDGKTSKVRFADVAGSEE 200 EcFtsH YTTYIPVQDPKLLD.... NLLTKNVKVVGEPPEEPSLLASIFISWFPMLLLIGVWIFFMROM... OGGGGKGAMSFGKSKARMLTEDQIKTTFADVAGCDE 159 Yme1p SSNQSGYHGNFPSMYSPLYGSRKEPLHVVVSESTFTVWSWVKWLLVFGILTYSFSEGFKYITENTTLLKSSEVADKS... VDVAKTN.VKFDDVCGCDE 288

TBP - 1

CDC1

CDC2

Pas1p

NSF

$\star * \star * *$ **

$\star G * \star$

G*PG*GKTL*A

*******

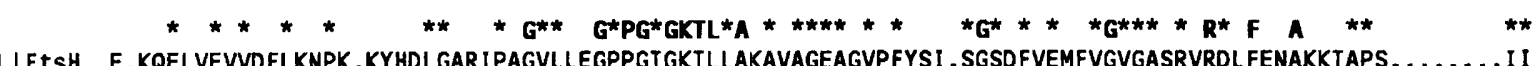
QYSDIGGLDK 158 GYDDIGGCRK 220 TWDDVGGLDE 493 KWGDIGALAN 704 EKMGIGGLDK 233 EcFtsH A.KEEVAELVEYLREPS.RFQKLGGKIPKGVLMVGPPGTGKTLLAKAIAGEAKVPFFT I.SGSDFVEMFVGVGASRVRDMFEQAKKAAPC........ 1 248 Yme1p A.RAELEEIVDFLKDPT.KYESLGGKLPKGVLLTGPPGTGKTLLARATAGEAGVDFFFM.SGSEFDEVYVGVGAKRIRDLFAQARSRAPA . . . . . I I 377 TBP-1 Q.1 QELLVEAIVLPMNHKEKFENLGI QPPKGVLMYGPPGTGKTLLARACAAQTKATFLKL.AGPQLVQMF I GDGAKLVRDAFALAKEKAPS ......11 248 CDC1 Q.MAQIREMVELPLRHPQLFKAIGIKPPRGVLMYGPPGTGKTLMARAVANETGAFFFLI .NGPEVMSKMAGESESNLRKAFEEAEKNAPA....... 11310 CDC2 I. KEELKETVEYPVLHPDQYTKFGLSPSKGVLFYGPPGTGKTLLAKAVATEVSANF I SV.KGPELLSMWYGESESN IRD I FDKARAAAPT .......VV 583 Pas1P A.KDVLLETLEWPTKYEPI FVNCPLRLRSGI LLYGYPGCGKTLLASAVAQQCGLNFISV.KGPEILNKFIGASEQNIRELFERAQSVKPC........IL 794 NSF EFSD I FRRAFASRVFPPE IVEQMGCKHVKGILLYYGPPGCGKTLLAROI GKMLNAREPKVVNGPE I LNKYVGESEANIRKLFADAEEEQRRLGANSGLHII 333

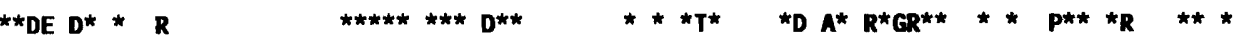

LIFtsH FIDEIDAVGRQRGAGLGGGDEREQTLNQLLVEMDGFQDDGNSVIVIAATNRSDVLDPALLRPGRFDRKVLVGAPDVKGREAVLKVHA.......KN.K 380

ECF tsH FIDE IDAVGRQRGAGLGGGHDEREQTLNQMLVEMDGFEGN.EGI IVIAATNRPDVLDPALLRPGRFDRQVVVGLPDVRGREQILKVHM........RR.V 338

Yme1p FIDELDAIGGKRNP...KDQAYAKQTLNQLLVELDGFSQT.SGI I I IGATNFPEALDKALTRPGR FDKVVNVDLPDVRGRAD I LKHHM........KK. I 464 TBP-1 FIDELDAIGTKRFDSEKAGDREVQRTMLELLNQLDGFOPNTQ.VKVIAATNRVDILDPALLRSGRLDRKIEFPMPNEEARARIMQIHS........RK.M 338 CDC1 FIDEIDSIAPKRDKTNG....EVERRVVSQLLTLMDGMKARSN.VWVIAATNRPNSIDPALRRFGRFDREVDIGIPDATGRLEVLRIHT ........KN.M 397 CDC2 FLDELDSIAKARGGSLGDAGGASDRVVNGLLTEMDGMNAKKN.VFVIGATNRPDQIDPAILRPGRLDQL IYVPLPDENARLSILNAQL.......RK.T 673 Pas1P FFDEFDSIAPKRGH... DSTGVTDRVVNGLLTOMDGAEGLDG.VYILAATSRPDLIDSALLRPGRLDKSVICNIPTESERLD ILQAIVNSKDKDTGQKKF 890 NSF I FDEIDAICKQRG. SMAGSTGVHDTVVNQLLSKIDGVEQLNN. I LVIGMTNRPDLIDEALLRPGRLEVKME I GLPDEKGRLQILHI HTARM.....RGHQ 426

$$
\text { ** * A *** Ga** * } A^{*} * * * * * * * * * * * \quad * *
$$

LlFtsH PLASDVDLHNVATOTPGYVGADLENVLNEAALVAARQNKKEINAADIDEGMDRAMAGPAKKDRIOSMREREIVAYHEAGHAIVGLVLENGSTVRKVTVVP 480 ECF TSH PLAPDIDAAI IARGTPGFSGADLANLVNEAALFAARGNKRVVSMVEFEKAKDKIMMGAERRSMVMTEAQKESTAYHEAGHAIIGRLVPEHDPVHKVTIIP 438 Yme1P TLADNVDPTIIARGTPGLSGAELANLVNQAAVYACOKNAVSVDMSHFEWAKDKILMGAERKTMVLTDAARKATAFHEAGHAIMAKYTNGATPLYKATILP 564 TBP-1 NVSPOVNYEELARCTDDFNGAQCKAVCVEA 368 CDC1 KLADDVDLEALAAETHGYVGADIASLCSEA CDC2 PLEPGLELTAIAKATOGFSGADLLYIVQRA 703 Pas1P ALEKNADLKLIAEKTAGFSGADLQGLCYNA NSF LLSADVDIKELAVETKNFSGAELEGLVRAA 456

LIFTSH RGRIGGYMLALPDEE IMQPTNFHLQDQLASLMGGRLGEEIVFGVA. . TPGASNDIEKATHIARSMVTEYGMSKKLGMVSY.EGDHQVFIGRDYGQTKTYS 577 ECF tSH RGRALGVTFFLPEGDAISASRQKLESOISTLYGGRLAEE I IYGPEHVSTGASNDIKVATNLARNMVTOWGFSEKLGPLLYAEEEGEVFLGRSVAKAKHMS 538 Yme1p RGRALGI TFQLPEMDKVDITKRECQARLDVCMGGKIAEELIYGGKDNT TSGCGSDLQSATGTARAMVTOYGMSDDVGPVNLSEN.... WESWS. NKIRD.. 657

$$
\text { *** } \quad * * \quad * * * * * *
$$

LIFTSH EATAVMIDDEVRRILGEAYDRAKEAIETHRECHKAIAEALLKYETLDAKQIMSLFKTGKMPDEAAAAEVPEPKTFEESLKDANANVDDF.SNINIYNGDE 676 ECF tsH DETARI IDGEVKAL IERNYNRARQLLTDNMD ILHAMKDALMKYET IDAPQIDDLM..........ARRDVRPPAGWEEP...GASNNSGDNGSPKAPRPVDE 627 Yme1p $\quad \ldots \ldots$. IADNEVIELLKDSEERARRLLTKKNVELHRLAQGLIEYETLDAHEIEQV..........CKGEKLD.....KLKTSTNTVVEGPDSDERKDIGD 736

LIFTsH KTDSKPEENKEKSEDETAE

Yme1P DKPKIP...TMLNA

Fig. 2. Amino acid sequence alignment of L. lactis (LI) FtsH, E. coli (EC) FtsH, Yme1p and the conserved domains found in L. lactis FtsH (residues 191-410); TBP-1 (Nelbock et al., 1990); CDC48p (CDC1, CDC2; CDC48p contains two conserved domains) (Fröhlich et al., 1991); Pas1p (Erdmann et al., 1991); and NSF (Wilson et al., 1989). S4 of the 265 protease, MSS1 and SUG1 resembling TBP-1 (Dubiel et al., 1992; Shibuya et al., 1992; Swaffield et al., 1992), VCP and p97 resembling CDC48p (Koller \& Brownstein, 1987; Peters et al., 1990), and Sec18p resembling NSF (Eakle et al., 1988) also contain the conserved domain (not shown). Identical amino acid residues found in these sequences are indicated in boldface type above the sequences. Identical amino acid residues of $L$. lactis $\mathrm{FtsH}, E$. coli FtsH and $Y m e 1 p$ are indicated by asterisks. The two putative membrane-spanning sequences of $L$. lactis $\mathrm{FtsH}$ and $E$. coli $\mathrm{FtsH}$ are underlined. 
(a)

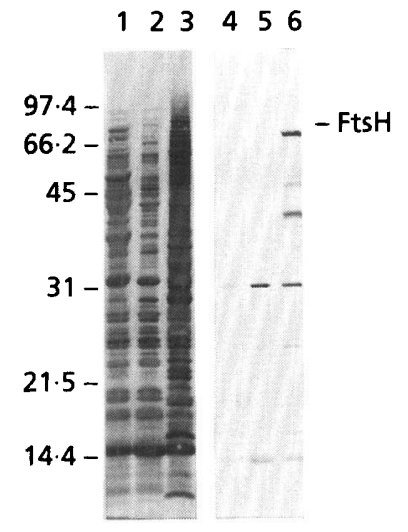

(b)

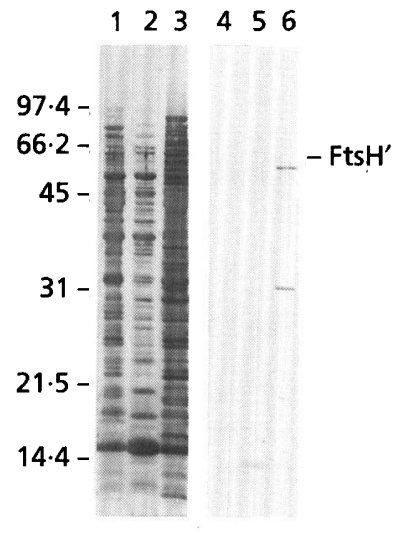

(a)

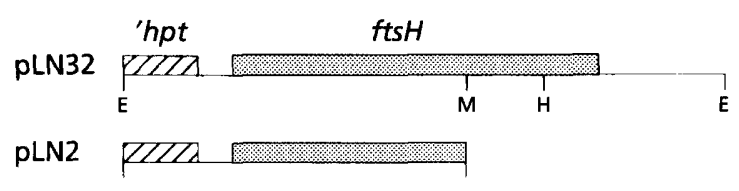

pLN39

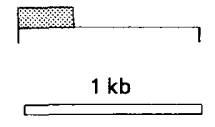

(b)

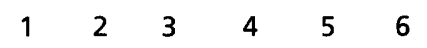

Fig. 3. Localization of $L$. lactis FtsH in cell fractions. Fractionation of extracts from MG1363 and DN4302, and treatment of membrane fractions with $1 \mathrm{M} \mathrm{NaCl}$ were done as described in Methods. Electrophoresis of the cell fractions on an SDS-polyacrylamide gel (a and b) was done, blotted to nitrocellulose and gold-stained (lanes 1-3) or subjected to Western blotting with anti-E. coli FtsH serum (lanes 4-6). Positions of molecular mass reference markers, FtsH and a truncated form of FtsH ( $\left.\mathrm{FtsH}^{\prime}\right)$ are indicated. All other bands are a result of unspecific binding of the secondary anti-serum used (control not shown). (a) Lanes: 1 and 4 , cytoplasmic fraction of MG1363; 2 and 5, supernatant derived from membrane fraction of MG1363 washed with $1 \mathrm{M} \mathrm{NaCl} ; 3$ and 6, pellet derived from membrane fraction of MG1363 washed with $1 \mathrm{M} \mathrm{NaCl}$. (b) Lanes: same as (a) except extract from DN4302 was used.

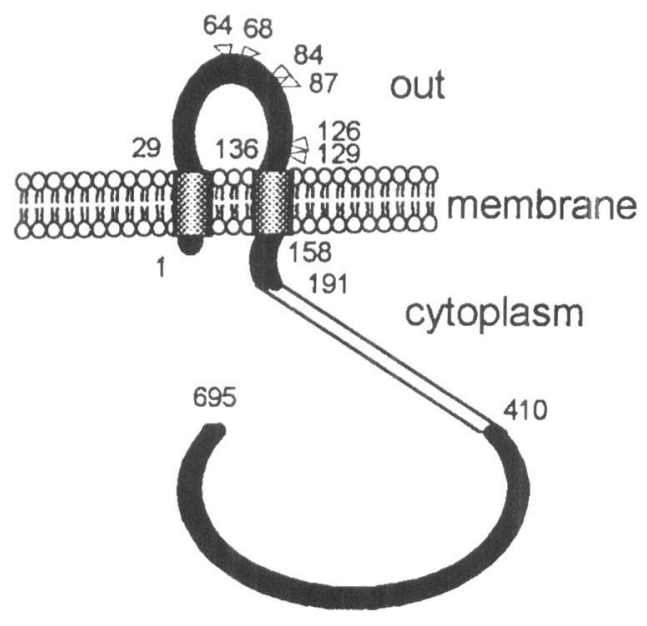

Fig. 4. Deduced topology of the L. lactis FtsH protein. Numbers indicate amino acid residue positions. Shaded boxes illustrate putative membrane-spanning regions. The encoded FtsH-PhoA fusions of pLN22-27 that results in AP activity are fused at positions indicated by triangles. The region with similarity to the conserved region of the AAA-protein family is indicated by an open box. This region contains the ATP binding motifs.

demonstrates that AR3120 was able to grow without the essential $E$. coli fts $H$ gene product when containing the $L$. lactis ftsH gene product. The plasmid pLN2 encodes a truncated $L$. lactis $\mathrm{FtsH}$ protein containing the epitope for the anti-E. coli FtsH serum, when transcribed and

Fig. 5. Immunological detection of $L$. lactis FtsH and $E$. coli FtsH. (a) The lines represent $L$. lactis chromosomal DNA fragments cloned in pBluescript $\mathrm{KS}+$ or SK-. The restriction enzyme sites shown are: E, EcoRI; H, HindIII; M, Mbol. The location of the $L$. lactis 'hpt and $\mathrm{fts} H$ genes is indicated by hatched and shaded areas, respectively. (b) Western blot. The $\mathrm{FtsH}$ proteins of $L$. lactis (LI) and $E$. coli $(\mathrm{EC})$ were detected using anti-E. coli FtsH serum. The positions of $L$. lactis FtsH and $E$. coli FtsH are indicated to the left. Lanes: 1, AR423(pKS +); 2, AR423(pLN39); 3, AR423(pLN2); 4, AR3120; 5, AR423(pLN32); 6 , AR423. The molecular mass reference markers are indicated on the right.

translated in vitro (Nilsson \& Lauridsen, 1992; data not shown). This truncated FtsH was not detected by the antiE. coli FtsH serum in the Western blot, possibly due to rapid degradation in vivo.

E. coli AR3120 showed temperature-sensitive growth in that it could grow at $30^{\circ} \mathrm{C}$ and $37^{\circ} \mathrm{C}$ but not at $42^{\circ} \mathrm{C}$. A B. subtilis mutant with a salt-sensitive phenotype has been shown to be impaired in a putative homologue of $\mathrm{ftsH}$ (Geisler \& Schumann, 1993). AR423, AR423(pLN32) and AR3120 were tested for growth on LB agar plates containing $4 \%(\mathrm{w} / \mathrm{v}) \mathrm{NaCl}$. AR423 and AR423(pLN32), but not AR3120, were able to grow on this medium.

\section{Construction of a $L$. lactis ftsH mutant}

A $1.3 \mathrm{~kb}$ EcoRV fragment of pLN32, containing an internal part of L. lactis fts $H$ (Fig. 1), was cloned into the L. lactis integration vector $\mathrm{pV} 2$ giving $\mathrm{pLN} 43$ (Table 1). 


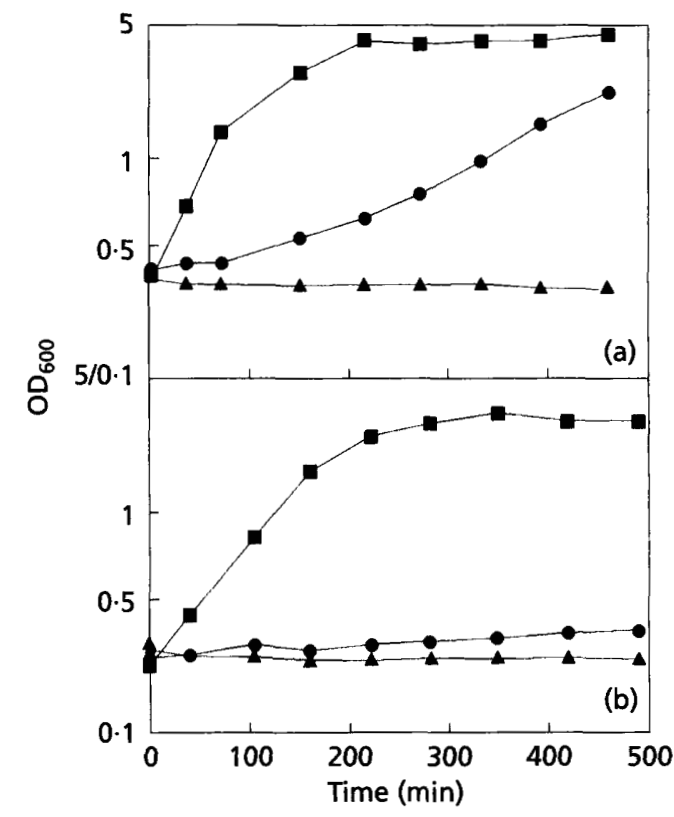

Fig. 6. Growth of $\mathrm{DN} 4302$ and $\mathrm{MG} 1363$ at various $\mathrm{NaCl}$ concentrations. MG1363 (a) and DN4302 (b) were grown exponentially in M17 medium and then diluted twofold in M17 medium containing $0 \%(\boldsymbol{G}), 4 \%(\mathbf{O})$ or $7 \%(\boldsymbol{\Delta})(\mathrm{w} / \mathrm{v}) \mathrm{NaCl}$ (final concentrations).

Transformation of pLN43 into L. lactis strain MG1363, selecting for erythromycin resistance, resulted in strain $\mathrm{DN} 4302 \mathrm{ftsH}:: p L N 43$. The integration of pLN43 into $f t s H$ of DN4302 was verified by Southern hybridization analysis (not shown). The construction of DN4302 indicates that the fts $\mathrm{H}$ gene is not essential in L. lactis or that the truncated form of FtsH encoded by the disrupted $f t_{s} \mathrm{H}$ gene (Fig. 3b, lane 6) is enough to retain any essential function. DN4302 and MG1363 were tested for growth on M17-agar plates containing $4 \%$ or $1 \% \mathrm{NaCl}$. MG1363 could grow at both $4 \%$ and $1 \% \mathrm{NaCl}$, whereas DN4302 grew slowly at $1 \%$ and not at all at $4 \% \mathrm{NaCl}$. Fig. 6 shows the growth of DN4302 and MG1363 at various salt concentrations in M17 broth. MG1363 grew at $4 \% \mathrm{NaCl}$ after a lag phase of about $2 \mathrm{~h}$, whereas DN4302 at $4 \%$ $\mathrm{NaCl}$ showed almost no growth. No growth of either strains occurred with $7 \% \mathrm{NaCl}$ DN4302 and MG1363 were also tested for growth on M17-agar plates containing $0.5 \mathrm{M}$ sucrose. Both strains appeared to grow equally well on this medium.

Growth at $38^{\circ} \mathrm{C}, 30^{\circ} \mathrm{C}$ and $16^{\circ} \mathrm{C}$ on M17-agar plates was also tested. DN4302 only grew at $30^{\circ} \mathrm{C}$, whereas MG1363 grew at all temperatures. However, incubating DN4302 anaerobically restored growth at $38^{\circ} \mathrm{C}$.

\section{Homologous genes in other bacteria}

A $1.0 \mathrm{~kb}$ HindIII-KpnI fragment (nucleotides 667-1600, Fig. 1) was used as probe in Southern hybridization analysis with $S_{c a I}$-digested chromosomal DNA from various bacterial strains (Fig. 7). Single chromosomal bands can be detected from the Gram-positive bacteria $L$. lactis, B. subtilis, Leuconostoc sp. and Lactobacillus sp. (Fig. 7, lanes $1,3-8)$. With $E$. coli DNA only a very faint band was detected (Fig. 7, lane 2). Under the same experimental conditions, homology to $b p t$, using a $b p t$ probe, was only detected in L. lactis (results not shown).

\section{DISCUSSION}

The $f t s H$ gene of $L$. lactis was cloned and shown to encode a transmembrane protein with putative ATPase activity. The deduced amino acid sequence indicates that FtsH belongs to the AAA-protein family of putative ATPases containing several members of eukaryotic proteins (Erdmann et al., 1991; Kunau et al., 1993) and also includes the membrane protein $\mathrm{FtsH}$ of $E$. coli (Tomoyasu et al., 1993a, b). FtsH from L. lactis and E. coli seem to be homologous proteins based on the high similarity of the amino acid sequences and that the $L$. lactis fts $H$ gene can complement certain defects of an E. coli $\Delta f t s H 3:$ :kan strain. Southern hybridization analysis of various Grampositive bacteria using $L$. lactis $f t s H$ as probe suggests that homologous genes exist. In $B$. subtilis a putative $f t s H$ gene has been located on the chromosome of B. subtilis adjacent to the $h p t$ gene (Geisler \& Schumann, 1993; Ogasawara $e t$ al., 1994), indicating a similar arrangement of $h p t$ and $f t s H$ as in L. lactis. It seems from these results that $f t s H$ genes are widely conserved in bacteria.

The function of $\mathrm{FtsH}$ is unknown. Our L. lactis fts $\mathrm{H}$ mutant and the $B$. subtilis fts $H$ mutant (Geisler \& Schumann, 1993) were constructed by a Campbell-type integration with an internal gene fragment. This should inactivate the genes. In E. coli, fts $\mathrm{H}$ is essential for growth. Since the resulting mutants are viable, it is possible that the $f t s H$ genes are not essential in L. lactis and B. subtilis. However, in at least $L$. lactis, the truncated form of FtsH produced by the mutant DN4302 may still retain essential functions.

The L. lactis fts $\mathrm{H}$ mutant $\mathrm{DN} 4302$ is impaired in salt tolerance and other stress responses, and shows a different pattern of membrane-associated proteins compared to the wild-type strain (Fig. 3, lanes 2). These phenotypes could be explained by an improper assembly of membrane proteins, some necessary for the salt tolerance, caused by the $f t s H$ mutations in L. lactis. In E. coli the maturation of penicillin binding protein 3 (PBP3) and $\beta$-lactamase is dependent on FtsH function, in that post-translational processing at the C-terminal part of PBP3 seems to be defective and accumulation of the plasmid-encoded precursor of $\beta$-lactamase in the cytoplasm was observed in the thermosensitive fts 11 mutant of E. coli (Begg et al., 1992; Tomoyasu et al., 1993a). Analysis of several newly constructed $E$. coli fts $H$ mutants encoding FtsH variants, including C-terminally truncated forms with dominant phenotypes, suggests that $\mathrm{FtsH}$ is involved in assembly/ folding of proteins into and through the membrane and that $\mathrm{FtsH}$ is needed to assure efficient stop-transfer of some membrane proteins (Akiyama et al., 1994a, b). 


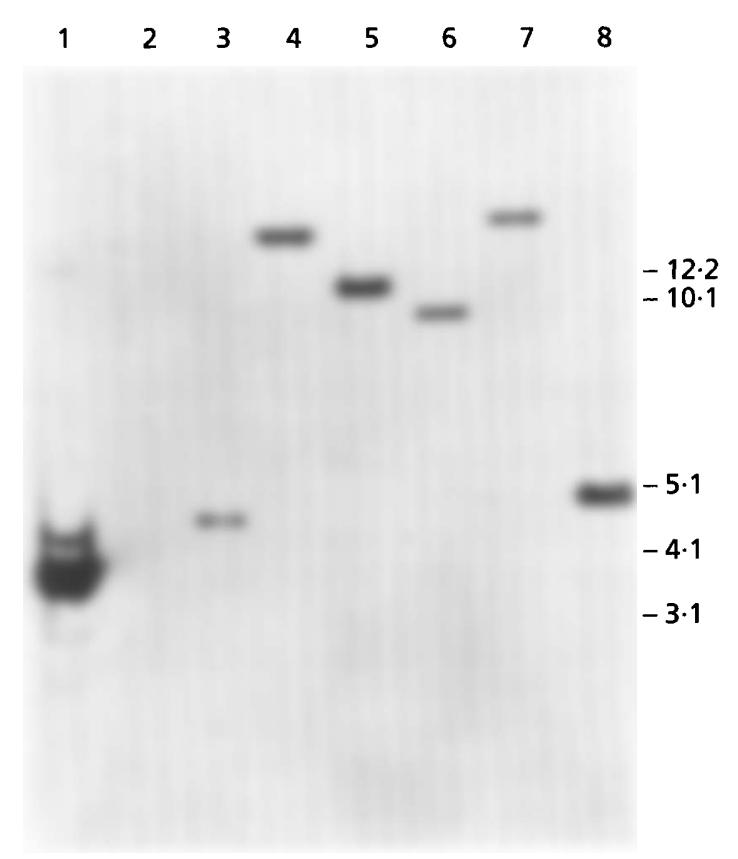

Fig. 7. Southern hybridization of an internal part of the $L$. lactis $\mathrm{ftsH}$ gene to chromosomal DNA from various bacteria. Lanes: 1, L. lactis CHCC285; 2, E. coli XL-1 Blue; 3, B. subtilis 168; 4, Leuconostoc mesenteroides DB1165; 5, Leu. óenos LOP89005; 6 Lactobacillus plantarum LP2T1G; 7, Lactob. acidophilus LA2753; 8, Lactob. lactis $\mathrm{CH}-2$. Molecular mass markers are shown on the right in $\mathrm{kb}$.

However, how FtsH is functionally related to these phenotypes is not known. Recently it was shown that a $b f B$ mutation in E. coli causing increased lysogenization frequencies of bacteriophage $\lambda$ through a reduced degradation of the $c \mathrm{II}$ protein, is located in $f t s \mathrm{H}$, and the $\mathrm{HflB} / \mathrm{FtsH}$ protein has been suggested to be an energydependent chaperone and/or protease (Herman et al., 1993). Other members of the AAA-protein family are also involved in proteolysis, e.g. subunit 4 of the human ATPdependent $26 \mathrm{~S}$ protease, and it was proposed that other eukaryotic members such as Tbp1, Sug1 and MSS1 are also subunits of the 26S protease (Dubiel et al., 1992). Taken together FtsH might function as a chaperone and/or a protease although no direct biochemical evidence for these functions has been reported so far. Comparative biochemical and genetic analysis of $\mathrm{FtsH}$ from $L$. lactis and $E$. coli will provide better understanding of the biological significance of $\mathrm{FtsH}$, if it is a chaperone or a protease, and what are its substrates.

\section{ACKNOWLEDGEMENTS}

We are pleased to thank: Eric Johansen, Egon Bech Hansen (Chr. Hansen's Laboratorium, Hørsholm, Denmark) and Per Nygaard (Enzyme division, Copenhagen University, Denmark) for careful reading of the manuscript; Henrik Ipsen (ALK, Denmark) for discussion; Eric Johansen for providing chromosomal DNA from Leuconostoc spp. and Lactobacillus spp.; Svend E. W. Hansen for the integration vector $\mathrm{pV} 2$; and Hans Henrik Saxild (Danish Technical University, Lyngby,
Denmark) for Bacillus subtilis 168 . We are also grateful to Michael Blom Sørensen (Carlsberg Laboratories, Denmark) for the provision of customized synthetic oligonucleotides and Thomas Laybourn and Lotte Friberg (ALK, Denmark) for technical assistance with the Western blots. This work was supported by a Grant-in-Aid for Scientific Research from the Ministry of Education, Science and Culture of Japan and the Lundbeck Foundation in Denmark.

\section{REFERENCES}

Akiyama, Y., Ogura, T. \& Ito, K. (1994a). Involvement of FtsH in protein assembly into and through the membrane. I. Mutations that reduce retention efficiency of a cytoplasmic reporter. $J$ Biol Chem 269, 5218-5224.

Akiyama, Y., Shirai, Y. \& Ito, K. (1994b). Involvement of FtsH in protein assembly into and through the membrane. II. Dominant mutations affecting FtsH function. $J$ Biol Chem 269, 5225-5229.

Begg, K. J., Tomoyasu, T., Donachie, W. D., Khattar, M., Niki, H., Yamanaka, K., Hiraga, S. \& Ogura, T. (1992). Escherichia coli mutant Y16 is a double mutant carrying thermosensitive $f t s H$ and $f t s I$ mutations. J Bacteriol 174, 2416-2417.

Birnboim, H. C. \& Doly, J. (1979). A rapid alkaline extraction procedure for screening recombinant plasmid DNA. Nucleic Acids Res 7, 1513-1523.

Clark, D. J. \& Maaløe, O. (1967). DNA replication and the division cycle in Escherichia coli. J Mol Biol 23, 99-112.

Devereux, J., Haeberli, P. \& Smithies, O. (1984). A comprehensive set of sequence analysis programs for the VAX. Nucleic Acids Res 12, 387-395.

Dubiel, W., Ferrell, K., Pratt, G. \& Rechsteiner, M. (1992). Subunit 4 of the $26 \mathrm{~S}$ protease is a member of a novel eucaryotic ATPase family. J Biol Chem 267, 22699-22702.

Eakle, K. A., Bernstein, M. \& Emr, S. D. (1988). Characterization of a component of the yeast secretion machinery: identification of the SEC18 gene product. Mol Cell Biol 8, 4098-4109.

Erdmann, R., Wiebel, F. F., Flessau, A., Rytka, J., Beyer, A., Fröhlich, K. \& Kunau, W. (1991). $P A S 1$, a yeast gene required for peroxisome biogenesis, encodes a member of a novel family of putative ATPases. Cell 64, 499-510.

Fröhlich, K., Fries, H., Rüdiger, M., Erdmann, R., Botstein, D. \& Mecke, D. (1991). Yeast cell cycle protein CDC48p shows fulllength homology to the mammalian protein VCP and is a member of a protein family involved in secretion, peroxisome formation, and gene expression. J Cell Biol 114, 443-453.

Gasson, M. J. (1983). Plasmid complements of Streptococcus lactis NCDO 712 and other lactic streptococci after protoplast-induced curing. J Bacteriol 154, 1-9.

Geisler, U. \& Schumann, W. (1993). Isolation of stress mutants of Bacillus subtilis by a novel genetic method. FEMS Microbiol Lett 108, 251-254.

Gutierrez, C., Barondess, J., Manoil, C. \& Beckwith, J. (1987). The use of transposon $\operatorname{Tn} p h o A$ to detect genes for cell envelope proteins subject to a common regulatory stimulus. J Mol Biol 195, 289-297.

Hanahan, D. (1983). Studies on transformation of Escherichia coli with plasmids. $J$ Mol Biol 166, 557-580.

Henkin, T. M., Donnelly, C. E. \& Sonenshein, A. L. (1988). Mutations in the spacer region of a Bacillus subtilis promoter. In Genetics and Biotechnology of Bacilli, Vol. 2, pp. 63-67. Edited by A. T. Ganesan \& J. A. Hoch. San Diego: Academic Press.

Herman, C., Ogura, T., Tomoyasu, T., Hiraga, S., Akiyama, Y., Ito, K., Thomas, R., D'Ari, R. \& Bouloc, P. (1993). Cell growth and $\lambda$ 
development controlled by the same essential Escherichia coli gene, ftsH/hflB. Proc Natl Acad Sci USA 90, 10861-10865.

Holo, H. \& Nes, I. F. (1989). High-frequency transformation, by electroporation, of Lactococcus lactis subsp. cremoris grown with glycine in osmotically stabilized media. Appl Environ Microbiol 55, 3119-3123.

Ipsen, H. \& Larsen, J. N. (1988). Detection of antigen-specific IgE antibodies in sera from allergic patients by SDS-PAGE immunoblotting and crossed radio-immunoelectrophoresis. In Handbook of Immunoblotting of Proteins, Vol. II, pp. 159-166. Edited by O. Bjerrum \& N. H. H. Heegaard. Boca Raton: CRC Press.

Jochimsen, B., Nygaard, P. \& Vestergaard, T. (1975). Location on the chromosome of Escherichia coli of genes governing purine metabolism. Mol \& Gen Genet 143, 85-91.

Johansen, E. \& Kibenich, A. (1992). Characterization of Leuconostoc isolates from commercial mixed-strain mesophilic starter cultures. $J$ Dairy S $i$ 75, 1186-1191.

Koivula, T., Sibakov, M. \& Palva, I. (1991). Isolation and characterization of Lactococcus lactis subsp. lactis promoters. Appl Environ Microbiol 57, 333-340.

Koller, K. J. \& Brownstein, M. J. (1987). Use of a cDNA clone to identify a supposed precursor protein containing valosin. Nature $325,542-545$.

Kunau, W. H., Beyer, A., Franken, T., Götte, K., Marzioch, M., Saidowsky, J., Skaletz-Rorowski, A. \& Wiebel, F. F. (1993). Two complementary approaches to study peroxisome biogenesis in Saccharomyces cerevisiae: forward and reversed genetics. Biochimie 75, 209-224.

Kyte, J. \& Doolittle, R. F. (1982). A simple method for displaying the hydropathic character of a protein. J Mol Biol 157, 105-132.

Larsen, J. N., Strøman, P. \& Ipsen, H. (1992). PCR based cloning and sequencing of genes encoding the tree pollen major allergen Car b I from Carpinus betulus (hornbeam). Mol Immunol 29, 703-711.

Ludwig, W., Seewaldt, E., Klipper-Balz, R., Schleifer, K. H., Magrum, L., Woese, C. R., Fox, G. E. \& Stackebrandt, E. (1985). The phylogenetic position of Streptococci and Enterococcus. $J$ Gen Microbiol 131, 543-551.

Mandel, M. \& Higa, A. (1970). Calcium-dependent bacteriophage DNA infection. J Mol Biol 53, 159-162.

Manoil, C. \& Beckwith, J. (1985). Tnpho $A$ : a transposon for protein export signals. Proc Natl Acad Sci US A 82, 8129-8133.

Manoil, C. \& Beckwith, J. (1986). A genetic approach to analyzing membrane protein topology. Science 233, 1403-1408.

Miller, J. H. (1972). Experiments in Molecular Genetics. Cold Spring Harbor, NY: Cold Spring Harbor Laboratory.

Moran, C. P., Jr, Lang, N., Le Grice, F. S. J., Lee, G., Stephens, M., Sonenshein, A. L., Pero, J. \& Losick, R. (1982). Nucleotide sequence that signals the initiation of transcription and translation in Bacillus subtilis. Mol \& Gen Genet 186, 339-346.

Nelbock, P., Dillon, P. J., Perkins, A. \& Rosen, C. A. (1990). A cDNA for a protein that interacts with the human immunodeficiency virus Tat transactivator. Science 248, 1650-1653.

Nilsson, D. \& Johansen, E. (1994). A conserved sequence in tRNA and rRNA promoters of Lactococcus lactis. Biochim Biopbys Acta (in press).

Nilsson, D. \& Lauridsen, A. A. (1992). Isolation of purine auxotrophic mutants of Lactococcus lactis and characterization of the gene bpt encoding hypoxanthine guanine phosphoribosyltransferase. Mol \& Gen Genet 235, 359-364.

Ogasawara, N., Nakai, S. \& Yoshikawa, H. (1994). Systematic sequencing of the 180 kilobase region of the Bacillus subtilis chromosome containing the replication origin. DNA Res 1, 1-14.

Ogura, T., Tomoyasu, T., Yuki, T., Morimura, S., Begg, K. J., Donachie, W. D., Mori, H., Niki, H. \& Hiraga, S. (1991). Structure and function of the $f t s H$ gene in Escherichia coli. Res Microbiol 142, 279-282.

Peters, J.-M., Walsh, M. J. \& Franke, W. W. (1990). An abundant and ubiquitous homo-oligomeric ring-shaped ATPase particle related to the putative fusion proteins Sec18p and NSF. EMBO J 9 , $1757-1767$.

Sanger, F., Nicklen, S. \& Coulson, A. R. (1977). DNA sequencing with chain-terminating inhibitors. Proc Natl Acad Sci US A 74, 5463-5467.

Shibuya, H., Irie, K., Ninomiya-Tsuji, J., Goebl, M., Taniguchi, T. \& Matsumoto, K. (1992). New human gene encoding a positive modulator of HIV Tat-mediated transactivation. Nature 357, $700-702$.

Shine, J. \& Dalgarno, L. (1974). The 3 '-terminal sequence of Escherichia coli $16 \mathrm{~S}$ ribosomal RNA: complementarity to nonsense triplets and ribosome binding sites. Proc Natl Acad Sci US A 71, 1342-1346.

Silhavy, T. J., Berman, M. L. \& Enquist, L. W. (1984). Experiments with Gene Fusions. Cold Spring Harbor, NY: Cold Spring Harbor Laboratory.

Swaffield, J. C., Bromberg, J. F. \& Johnston, S. A. (1992). Alterations in a yeast protein resembling HIV Tat-binding protein relieve requirement for an acidic activation domain in GAL4. Nature 357, 698-700.

Thorsness, P. E., White, K. H. \& Fox, T. D. (1993). Inactivation of YME1, a member of the ftsH-SEC18-PAS1-cdc48 family of putative ATPase-encoding genes, causes increased escape of DNA from mitochondria in Saccharomyces cerevisiae. Mol Cell Biol 13, 5418-5426.

Tomoyasu, T., Yuki, T., Morimura, S., Mori, H., Yamanaka, K., Niki, H., Hiraga, S. \& Ogura, T. (1993a). The Escherichia coli FtsH protein is a prokaryotic member of a protein family of putative ATPases involved in membrane functions, cell cycle control, and gene expression. J Bacteriol 175, 1344-1351.

Tomoyasu, T., Yamanaka, K., Murata, K., Suzaki, T., Bouloc, P., Kato, A., Niki, H., Hiraga, S. \& Ogura, T. (1993b). Topology and subcellular localization of FtsH protein in Escherichia coli.J Bacteriol 175, 1352-1357.

Walker, J. E., Saratse, M., Runswick, M. J. \& Gay, N. J. (1982). Distantly related sequences in the $\alpha$ - and $\beta$-subunits of ATP synthetase, myosin, kinases and other ATP-requiring enzymes and a common nucleotide binding fold. EMBO J 1, 945-951.

Wilson, D. W., Wilcox, C. A., Flynn, G. C., Chen, E., Kuang, W., Henzel, W. J., Block, M. R., Ullrich, A. \& Rothman, J. E. (1989). A fusion protein required for vesicle-mediated transport in both mammalian cells and yeast. Nature 339, 355-359.

von Wright, A., Tynkkynen, S. \& Suominen, M. (1987). Cloning of a Streptococcus lactis subsp. lactis chromosomal fragment associated with the ability to grow in milk. Appl Environ Microbiol 53, 1584-1688.

Received 14 March 1994; revised 31 May 1994; accepted 8 June 1994. 